\title{
VOYAGE OF THE DISCOVERY II
}

\author{
By Dr. N. A. MACKINTOSH, C.B.E.
}

$\mathrm{T}$ HE arrival at Plymouth on December 6 of the Royal Research Ship Discovery II marked the completion of a twenty-month voyage of oceanographical survey. It was her first voyage under the auspices of the National Institute of Oceanography, which was founded two years ago to do basic research in oceanography, and which was charged with continuing part of the work of the Discovery Committee. The purpose of this voyage was to round off the Committee's oceanographical work in the Southern Ocean, which in certain respects was incomplete. The Discovery II has made five previous voyages to this Ocean with the main purpose of studying the environmental factors which influence the distribution and movements of whales and other marine fauna; and the satisfactory execution of the work, which began in the Falkland Islands Dependencies, entailed a comprehensive oceanographical survey of the whole Southern Ocean. Coastal surveys were made by the ship's officers as opportunities occurred in intervals between the scientific work. The pages of the "Antarctic Pilot" bear frequent references to their observations, and the charts of the Dependencies are based largely on them.

The recent, post-war voyage was planned and timed so that observations could be made in regions and seasons of the year not sufficiently covered by the data collected before the Second World War. The Indian Ocean sector was visited in winter and summer, the Australian sector in autumn and winter, and the Pacific sector in spring and winter; and a winter cruise was made across the Atlantic sector. It was not the first time the ship had contended with cold, bad weather and short hours of daylight during winter months in high latitudes; but during this voyage the difficulties were somewhat increased through most of the ship's personnel being new to the work, and by the occasional appearance of defects for which the ship's arduous service during the war years was probably responsible. All the essential items in the programme were, however, carried out, and many gaps in the previous work have been filled.

The Southern Ocean is a continuous belt of deep water encircling a central land mass ; in consequence the prevailing currents and water circulation, and the fauna and flora, are distributed in a simpler pattern than in other oceans, and they are particularly suitable for a study of the large-scale physical, chemical and biological procosses. It is an advantage also that there are comparatively few species in the rich fauna and flora. The relative simplicity of the water conditions allows useful generalizations to be made from fewer data than in other oceans, and make this region an ideal laboratory in which to formulate and test basic principles for use in other parts of the world. Such work will necessarily take a long time. The newly supple. mented data will also be used for the more pedestrian task of compiling in some form an oceanographical atlas of the Southern Ocean, including charts, not only of surface temperature and ice conditions south of the usual tracks of shipping, but also of all the major oceanographical features of the Southern
Ocean. Such charts enable the whole region to be seen in perspective, and they are needed as a basis for the further study of the extensive biological data and collections. They are also required for examining the interchange of energy between the ocean and atmosphere, which is one of the most promising lines of marine physical investigation, and one which will improve our understanding of antarctic climatology and weather.

In spite of the circumpolar continuity of phenomena in the Southern Ocean, some sectors are more productive than others, and it will be necessary to examine carefully the connexion between such variations in the richness of animal and plant life, and variations in the strength of the water circulation and the movements and properties of the main water masses. This problem is bound up with the circulation of the plankton, which maintains an endemic population in the antarctic zone through interchange between the surface layer which drifts northwards and the underlying 'warm deep water' with a compensating drift to the south. Many of the commoner species of the zooplankton spend the summer in the surface layer and are carried back to high latitudes in winter in the deeper layer; others move from one to the other in their diurnal vertical migrations. The krill (Euphausia superba), which is the staple food of whales, and of many seals, birds and fish, lives close to the surface, but its eggs are hatched at depths probably exceeding $1,500 \mathrm{~m}$.; the larvæ pass through several stages as they rise through the southward drift to replenish the stock at the surface in high latitudes. Recent work has shown also that the drift from the Weddell Sea is the principal nursery of the krill. Thus the texture of the pelagic populations is beginning to be understood; but much painstaking work will yet be needed to relate the regional differences in the distribution and life-histories of such organisms with the distribution and habits of whales.

A detailed knowledge of the bottom topography of the ocean is essential to a full understanding of the water circulation, and during the recent voyage the Discovery II has supplemented her earlier depth charts by an enormous number of new echo-soundings, and has recorded many continuous bottom profiles, running the sounding machine for long periods. Information on the depths of bottom sediments was also obtained in a number of places by seismic echo soundings with $11-1 \mathrm{lb}$. explosive charges. Four long bottom cores were obtained in the Indian Ocean with a Kullenberg corer. South of Australia, the corer struck a hard substance-possibly a meteorito-on the bottom; the nose-piece was blocked with hard brownish-black material which had to be chipped out. It was handed to the Geological Department of the University of Western Australia for further examination.

A good deal of work was done for the Governments of Australia and New Zealand, which are represented on the National Oceanographic Council and contribute to the finances of the National Institute of Oceanography. Lines of physical and biological observations were made off the coast of New South Wales and in the Australian Bight for the Fisheries 
No 4289 January 12, 1952

Division of the Commonwealth Scientific and Industrial Research Organization, and a number of dredgings off the west coast of Australia for the University of Western Australia. Sounding and dredging were carried out in the Tasman Sea and south-east of New Zealand for the New Zealand Department of Scientific and Industrial Research. A number of Australian and New Zealand scientific workers were carried from time to time and given facilities on the ship, and one Australian biologist, Mr. E. H. M. Ealey, made the whole circumpolar voyage. Help was given to the stations of the Australian National Antarctic Research Expedition on Macquarie and Heard Islands. Stores were landed at Kerguelen for a French expedition, and diesel fuel at Heard Island.

Certain special investigations were included in the programme. One of these was concerned with the Antarctic Convergence, a region of sudden increase in surface temperature between antarctic and subantarctic water masses. This must now be regarded as similar to an atmospheric 'front' in which unstable waves grow into cyclones and anticyclones; but the new observations, while providing evidence of the eddies associated with such frontal developments, gave further indications that the mean position of the convergence remains remarkably constant.

Regular observations on birds made by the Third Officer, Mr. G. H. Selby-Smith, confirm the tendency of all pelagic life in the Southern Ocean to be dis. tributed in circumpolar zones.

In addition to the main survey of the Southern Ocean, observations have been made and repeated along the 90th E. meridian, through the central part of the Indian Ocean, about which there is little other oceanographical information except for a few recent and very useful observations by the French antaretic research vessel, Commandant Charcot. Lines of observations were made also from the Red Sea to the Indian Ocean during June 1950 and in the opposite direction during November 1951. The vertical sections indicate a larger submarine outflow in winter than in summer, but they emphasize the great irregularity of the bottom topography of the region, which makes quantitative comparison difficult. A line of stations was also worked through the Straits of Gibraltar.

During the twenty-month voyage of the Discovery $I I$, Cdr. J. F. Blackburn was in executive command, and the principal scientific officer in charge of the work was Dr. H. F. P. Herdman.

For the next year or two, while the results of the recent voyage are being analysed, the vessel will be employed mainly in research work aimed at furthering our understanding of some of the basic processes which affect the physical conditions and life in the sea. On the physical side, much of the effort will be devoted to studying the processes by which energy is exchanged between the sea and atmosphere, and transported from one area to another or exchanged between shallow and deep layers. It is hoped that a good deal will be done which is of direct interest to all oceanographers, and to save time and expense it will be done as near to the United Kingdom as the conditions most favourable for the experiments can be found. On the biological side, it is expected that much of the effort will be devoted to testing new methods of sampling, and to the study of the habits of some pelagic and bottom-living animals in relation to water conditions, nature and slope of the bottom, and other factors.

\section{FORESTRY IN GREAT BRITAIN}

\section{REPORT FOR THE YEAR 1949-50}

$\mathrm{T}$

WO reports dealing with forestry in Great Britain during the year 1949-50 have been issued by the Forestry Commissioners : the first is the thirtyfirst annual report of the Commissioners* and the other is an account of forest research that took place during the yeart. In their annual report the Commissioners were able to record that agreement had been reached with the representatives of private woodland owners with regard to the conditions under which landowners can dedicate their woodlands to the production of timber and manage them according to a plan of operations satisfactory to the Commissioners, in return for which they recejve certain financial aid from the Government. Objections to details in the contract of dedication had hitherto prevented the landowners' and forestry societies from recommending their members to come into the scheme, and the progress of dedication had been disappointingly slow. Now that these objections have been met, it is hoped that more rapid progress will be made. During the year the response was already apparent in an increase, from 248 to 374 , in the number of estates engaged in preparing plans for the effective management of their woodlands. Further encouragement to private forestry has been given by increasing the planting and maintenance grants and by giving support and encouragement to co-operative associations of small woodland owners for mutual help in managing their woods and marketing their produce. In spite of all efforts to bring about the rehabilitation of the 813,000 acres of woodlands classified as felled or devastated in the Census of Woodlands for 1947, most of which are privately owned, progress is distressingly slow, and the Commissioners feel that, unless there is a considerable improvement within a reasonable time in the rate at which private owners bring their woods into satisfactory production, they will have no option but to use their compulsory powers of acquisition.

Progress in the Commission's work of extending and managing the State forests has continued. The area of land acquired during the year was 109,000 acres, of which 61,000 were classified as "plantable". This brought the total area of land acquired by the Commission to $1,004,000$ acres of "forest land and 664,000 acres of other land", which includes forest nurseries, agricultural and grazing land, and other land unsuitable for planting. During the year, 53,737 acres were planted-an increase of about 10,000 acres on that planted in the previous year. The area thinned was 31,996 acres, and the area clearfelled 1,221 acres. Grants amounting to $£ 12,436$ were made to various universities for educational purposes, and five training schools for foresters were maintained by the Commissioners.

A brief account of the research and experimental work carried out or sponsored by the Commissioners is given in their annual report; but a fuller one appears in the separate report on forest research. This latter is divided into two sections, the first dealing with the work carried out by members of the staff of the Forestry Commission, and the second with work on

* Forestry Commission. Thirty-first Annual Report of the Forestry Commissioners for the Year ending September 30, 1950. Pp. 75. (London: H.M. Stationery Office, 1951.) 28. 6d. net.

$\dagger$ Forestry Commission. Report on Forest Research for the Year ending March 1950. Pp. 126. (London: H.M. Stationery Office, 1951.) 38. 6d. net. 